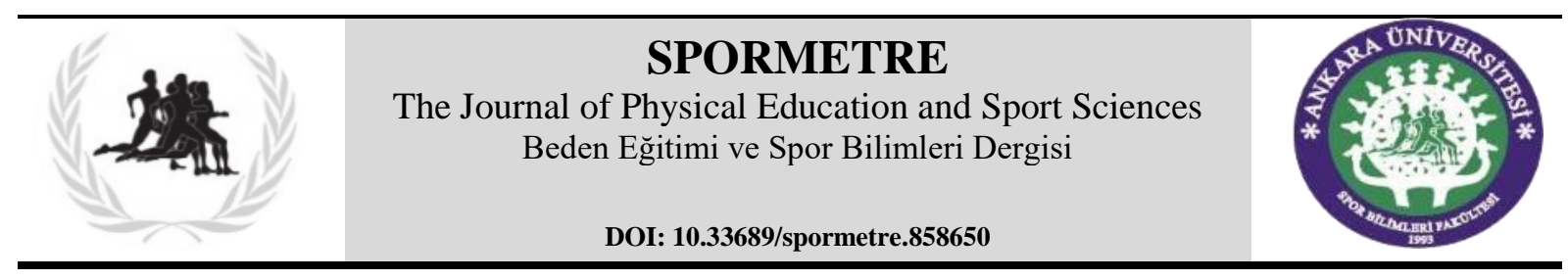

Geliş Tarihi (Received): 12.01.2021～Kabul Tarihi (Accepted): 01.06.2021ＯＩnline Yayın Tarihi (Published): 30.06 .2021

\title{
MULTI CRITERIA DECISION MAKING APPROACHES FOR EVALUATION OF EQUIPMENT SELECTION PROCESSES IN ROWING
}

\author{
Şeyma BOZKURT UZAN ${ }^{1 *}$, Mustafa SUBAȘI ${ }^{2 \mathbb{D}}$, Merve VURAL ALLAHAM ${ }^{1 \mathbb{C}}$ \\ ${ }^{1}{ }^{1}$ sstanbul Gelişim Üniversitesi, İktisadi, İdari ve Sosyal Bilimler Fakültesi, İSTANBUL \\ ${ }^{2}$ İstanbul Gelişim Üniversitesi, Lisansüstü Eğitim Enstitüsü, İSTANBUL
}

\begin{abstract}
The relevance and quality of the materials used in rowing, such as oars and rowing boats, directly affect the performance and success of the athletes in training and competitions. Using inappropriate and lowquality materials may cause the athlete to fail even if the athlete shows a very high performance. When procuring materials in rowing clubs, some factors such as the purpose of using the materials to be selected, the characteristics of the athletes and the budget of the club play a role in the selection of materials. At the material selection stage, the best quality material is preferred for high-level international athletes, and lower quality materials are preferred for intermediate and beginner athletes. In this sport's branch, the selection of the appropriate equipment to be used by the athletes appears as a decision-making problem because it involves many interacting factors and is very important for the success of the athletes. It is considered to use Multiple Criteria Decision Making (MCDM) techniques to solve this problem. In this article, an MCDM approach is proposed to solve such decision-making problems encountered in the rowing branch.
\end{abstract}

Key Words: Rowing, Equipment Selection in Rowing, Multi Criteria Decision Making, TOPSIS.

\section{KÜREK SPORUNDA EKIPMAN SEÇIM SÜREÇLERININ ÇOK KRITTERLI KARAR VERME YAKLAŞIMLARI İLE DEĞERLENDİRILMESI}

Öz: Kürek sporunda, sporcuların antrenmanlarda ve yarışmalardaki performansı ve başarısına kullanılacak kürek, tekne gibi malzemelerin uygunluğu ve kalitesi doğrudan etki etmektedir. Sporcu çok yüksek bir performans gösterse bile uygun olmayan ve kalitesiz malzemeler bu sporcunun başarısız olmasına neden olabilmektedir. Kürek kulüplerinde malzeme tedarik edilirken seçilecek malzemelerin hangi amaçla kullanılacağı, sporcuların özellikleri, kulübün bütçesi gibi bazı etkenler malzeme seçiminde rol oynamaktadır. Üst düzey uluslararası sporcular için en iyi kalite malzeme seçilirken, orta düzey sporcular ve yeni başlayanlar için daha düşük kalite malzeme tercih edilmektedir. Bu spor branşında sporcuların kullanılacağı uygun ekipman seçimi sporcuların başarısı için çok önemli olduğundan ve birçok faktöre etki edebileceğinden dolayı bir karar verme problemi olarak ortaya çıkmaktadır ve bu durum ÇKKV teknikleri kullanılarak çözülebilir. Mevcut makale kürek branşında karşılaşılan bu tür karar problemlerini çözmek için bir ÇKKV yaklaşımı önermektedir.

Anahtar Kelimeler: Kürek Sporu, Kürek Sporunda Ekipman Seçimi, Çok Kriterli Karar Verme, TOPSIS.

\section{INTRODUCTION}

In recent years, the importance of logistics is increasing with the rapid improvement of globalization and technology in the world. Firms that want to gain competitive advantage in every sector are trying to increase the quality of their goods and services while also trying to reduce the existing costs. Therefore, the decision they make in logistics activities has become important for companies that produce goods and services. New research has emerged about the logistics decisions made by companies and different sources have been added to the literature in this area. 
Logistics activities have an important place in sports and sports organizations. Purchasing decisions within these organizations directly affects both the sportive success and the satisfaction of the participants in the organizations. Especially in sports such as rowing, where the quality of the material directly affects the success of the athletes. To achieve sportive success and in this case, the correct use of the club budget and financial opportunities, the decision to purchase the material, the evaluation of the criteria in the purchasing process and the selection of the most appropriate material are very important.

For this reason, the logistical decision-making process in sports clubs emerges as one of the most important problems to be solved. In this process, almost everyone within the club, such as managers, athletes, trainers, coaches and suppliers, can be considered as decision makers.

In this article, the problem of multi criteria decision making regarding the criteria of the rowing boat to be purchased for club use is investigated. When previous studies are examined, it is seen that multi criteria decision making problems in logistics related to rowing sports have been discussed, but no research has been done on material purchasing. With this study, the multi criteria decision making method for purchasing a rowing boat in a rowing club was applied for the first time and contributed to the literature.

\section{SUPPLY AND DEMAND IN ROWING}

Nowadays, sports have become more professional and the investments made in sports have become a big industry, not limited to investments made only in clubs and athletes. All sectors benefit directly or indirectly from sports by following the developments. (Dorukkaya, 2000).

In these conditions, if a sports club wants to be successful, it must be operated as a professional company. Just as companies want to minimize cost and maximize profits, sports clubs want to minimize cost and maximize their success. In the last decade, the importance of logistics for sports clubs has been recognized after the importance of the logistical process in companies has been well understood. It is seen that issues related to logistics management such as supplier selection, fleet management, reverse logistics and choosing the location of the logistics center are widely discussed with Multi-Criteria Decision-Making methods in the literature. The Multi Criteria Decision Making method has been proposed for the use of a flexible reverse logistics approach (Karaköprü and Kabadurmuş, 2019).

All kinds of sports equipments used in sports activities in the sports industry, commercial or public space are also investigated in terms of sub-sector (Üçışık and Ekren, 2000). Rowing is a team sport performed in areas such as lakes, rivers and seas, where boats move and athletes compete with each other with the help of oars specially produced for this sport. Only $1 \mathrm{X}$ (single scull) boat class is individual. In this sport, which is considered to be one of the most difficult sports in the world, athletes are prepared for races by increasing their technical and conditioning training performances throughout the year (Türkiye Kürek Federasyonu, 2020).

Rowing is an outdoor nature sport. Therefore, it is affected by all kinds of weather conditions such as wind and waves. The aim is to advance the boat on the water as fast as possible. For this reason, the equipment and materials used have great importance in terms of success and performance.

Materials such as boats and oars used in rowing sport are made using advanced technology materials such as Carbon, Kevlar and light wood. Race boats have three equipments, internal, 
external and elbow equipment. External equipment; the shell part used on the outer surface of the boat, keel that keeps the boat balanced and running straight, rudder (available in some boat categories), safety ball on the head of the boat and numerator. Interior equipment materials are; foot stretcher, slide seat and a rail system that allows the seat to move back and forth. Hardware in outriggers which is a material made of metal or carbon extending towards the side of the boat and the "oarlock" system that attaches the oars mounted to this system and ensures its movement. These hardware systems on the boats reflect the power of the oarsman to the water, and the lever system of the boat provides the forward movement of the boat (Subaş1, 2019).

Purchasing is the supply of all necessary raw materials, machinery, needs etc. The purchasing activities are listed as follows (Tanyaş, 2009):

- Determination of all products and services that need to be purchased,

- Determination of the most suitable supplier,

- Making meetings with the supplier,

- Placing an order to the supplier,

- Tracking and controlling the order,

- Monitoring and evaluation of the purchasing process.

The aim is to minimize excess stock with "JIT: just in time", which is of great importance for businesses and manufacturers today. Thus, businesses tend to a more flexible production approach and reduce their stocks by meeting the demands and product variety quickly. This management understanding has increased the importance of stock management. In this way, some management functions such as determining the material needs, finding the materials needed, procuring them, and tracking the stock status have emerged (Lambert ve Stock, 2001).

Following the meetings with some managers and trainers in rowing clubs, the decision-making criteria that emerged during the process of purchasing the necessary equipment in rowing are as follows (Subaş1, 2019):

- Determination of needs,

- The budget and financial situation of the club,

- Features of club athletes (infrastructure-elite athletes, male-female athletes etc.),

- The sportive aim of the club,

- Evaluation of the demand of the athletes,

- Determination of the company that sells the needed material.

When the need for equipment (boats, oars) arises in rowing clubs, managers and trainers make the decision together. Once the needs have been identified, the budget and financial situation of the club are reviewed. After deciding what kind of material to purchase in line with the sportive purposes of the club, the material supply is carried out by negotiating with the material supplier to be purchased. Criteria such as; who will use the material to be purchased from the club athletes, for what purpose (sportive competitions, athlete training, etc.) are an important criterion in this selection process. For example; if the athletes who will use the boat are senior athletes, the boats and materials to be purchased are selected from those that can maximize the performance of these athletes. Even boat manufacturers have produced specially-designed boats according to the physical characteristics (height, weight, arm-leg length) of the athletes. However, if the boats to be purchased will be used by amateur athletes or more than one athlete and team, the boat dimensions are chosen as average. In addition, the demands and expectations of the athletes are taken into account in boat selections (Subaş1, 2019). 
Another criterion in the preferences of the manufacturer and brand in the purchasing process of sports equipment is the reliability and references of the brand. The usage of the boat brand in high-level international races (such as the Olympics, the world championships) and the fact that successful athletes prefer these brands are an important factor in choosing these brands in purchasing. After the boat is purchased, backup parts and after-sales technical support provided by the manufacturer are another reason for preference. Some boat companies provide maintenance and repair services for their own boats in international races in the racing area (Subaş1, 2019).

\section{LITERATURE REVIEW}

Logistics activities in sports, sports organizations and sports clubs are a new field of study in the literature. When the literature studies on sports clubs are examined, it is seen that there is no study on multi-criteria decision making in purchasing materials. Studies using different techniques related to purchasing sports equipment were found in the literature review.

Subaş1 (2019), examined the logistics activities in sports organizations with the Example of the National Rowing Races Organization, and investigated the effects of sports equipment purchasing and supply management on sports activities and organization success.

Karaköprü and Kabadurmuş (2019), used Electre and AHP method to examine the multi-criteria decision-making process in the selection of the bus to which athletes in football clubs will go to away matches.

Roscoe and Baker (2014) investigated the factors that affect supply chain segmentation when two sports equipment manufacturers in the sports equipment industry sell to consumers through retail chains.

Aytaç and Yenel (2012), examined the supporters of the three major football clubs in Turkey, in their purchase of products from their licensed product of the team they support.

Tarakçı and Baş (2018), investigated the extent to which sports sponsorship creates purchasing intention and brand awareness in consumers and the effects of the behaviors of the parties on purchasing decisions.

\section{DEFINITION OF PROBLEM}

As in rowing, the material selection and purchasing process is an important problem in sports branches where the materials used have a significant effect on the success of the athlete. After interviews with club managers and trainers who played a role in this decision-making process, 4 different boat brands and 7 criteria that are important in choosing these boat brands were revealed.

Since the characteristics of the athletes in the club may be different in every period, the boat purchased will be the ideal size and characteristics for the athletes of that year, but these features may not be suitable in the coming years. Therefore, the criteria determined in the multi-criteria decision-making research of each club and the leading boat manufacturers in the world are given in the table below (Table 1 and Table 2):

Table 1. Boat manufacturer companies 


\begin{tabular}{clcc}
\hline Rank & Boat Manufacturer & Code & Alternative \\
\hline 1 & Filippi & P1 & F \\
\hline 2 & Empacher & P2 & E \\
\hline 3 & Hudson & P3 & H \\
\hline 4 & WinTech & P4 & W \\
\hline
\end{tabular}

Table 2. Selection criteria in boat purchasing

\begin{tabular}{clc}
\hline Rank & Boat Selection Criteria & Code \\
\hline 1 & Boat price & $\mathrm{C} 1$ \\
\hline 2 & Boat brand recognition & $\mathrm{C} 2$ \\
\hline 3 & Boat quality & $\mathrm{C} 3$ \\
\hline 4 & The purpose of use of the boat (sportive purpose) & $\mathrm{C} 4$ \\
\hline 5 & Characteristics of athletes (level, gender etc.) & $\mathrm{C} 5$ \\
\hline 6 & Boat delivery time & $\mathrm{C} 6$ \\
\hline 7 & Technical support (backup parts, maintenance and repair etc.) & $\mathrm{C} 7$ \\
\hline
\end{tabular}

In rowing, the combination of many different groups of athletes such as female-male athletes, light weight category, amateur-elite athletes, and single scull (1X), double scull (2X), quad scull (4X), pair scull - pair with coxswain (2- / 2+), four scull - four wait coxswain (4- / 4+), and eight sculls (8+). Having eight different boat classes makes purchasing decisions very complicated. For example; when a lighter weight crew boat is used by heavyweight category crew, the friction will increase as the boat will sink further into the water, which will adversely affect the speed of the boat and therefore the performance of the athletes.

With the development of technology, the materials used in rowing (rowing-boats, oars etc.) are made of special materials that are very light and reduce friction. Therefore, when purchasing very expensive materials, all the conditions of the club are evaluated. When a boat purchased for elite athletes is used by amateur athletes and novices, there is a risk of damaging the boat, it is a great risk to use such high-level boats except for the athletes preparing for international races. However, cheaper boats are preferred for the amateurs, such boats are not very suitable for elite athletes.

This study was conducted to reduce the confusion and help the decision process in similar situations. In addition, it will be a guiding study for boat manufacturers in terms of boat marketing for rowing clubs.

\section{METHOD}

In this study, an integrated multi-criteria decision-making model is proposed to evaluate the selection of boats used in rowing sports consisting of Simple Additive Weighting (SAW), Stepwise Weight Assessment Ratio Analysis (SWARA) and Multi Attribute Utility Theory (MAUT) methods. Using the SAW method, the numerical values of the decision alternatives were determined according to the decision makers in the perspective of each selection criterion, then the relative weight values of the selection criteria were calculated using the SWARA method. Finally, the performance scores of decision alternatives were calculated using the MAUT method and the alternatives were ranked according to their importance. The implementation steps of the proposed model are shown in Figure 1:

Figure 1: Implementation steps of the proposed model 


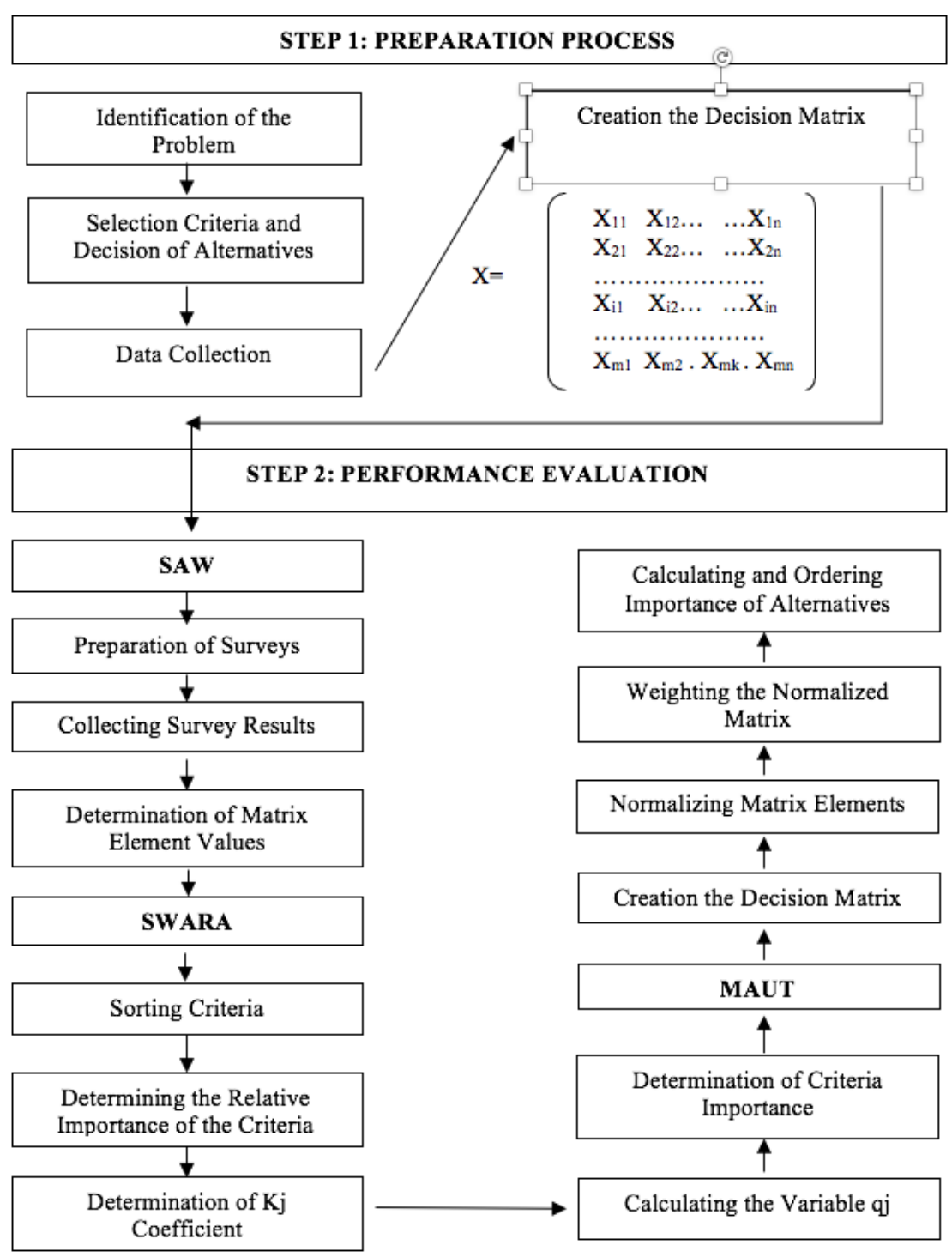

\section{Simple Additive Weighting (SAW)}

Simple Additive Weighting (SAW) is one of the methods used to convert verbal evaluation expressions to numerical values in cases where numerical values are not clear or verbal evaluation of decision makers is important. According to this approach, decision makers can score the importance values of the selection criteria from 1 to 9 , allowing the significance values to be defined as numerical values. At the same time, decision makers allow obtaining numerical value by scoring the determined decision alternatives according to the selection criteria. The values obtained are used in weighting the selection criteria and ranking the decision alternatives in the next steps.

\section{Step-wise Weight Assessment Ratio Analysis (SWARA)}

The SWARA method is a "Multi Criteria Decision Making" method used to overcome the uncertainties in the process of evaluating the specified criteria and alternatives with verbal expressions. This method was first introduced in Keršuliene, Zavadskas and Turskis (2010). Relatively, it is preferred as a criterion weighting method in this study because it is easy to apply and offers decision makers more opportunities to set priorities. The method consists of five application steps as shown below: 
Step 1: "Ranking of Criteria": Criteria are simply ordered in descending order, considering the order of importance in line with decision makers. If more than one decision maker will evaluate the criteria, a general ranking is formed by listing the criteria in descending order and taking the geometric averages of the criteria as a result of the evaluation made by each decision maker.

Step 2: "Determining the relative importance of each criterion": For this, it is determined how important the $j$. criterion is from $(j+1)$ criterion, by comparing $j$. criterion with $(j+1)$. For this comparison, the variable proposed by Keršuliene, Zavadskas and Turskis (2010) is denoted with $\mathrm{Sj}$ and named as "the comparative significance of the mean value".

Step 3: "Determining the coefficient kj": The coefficient kj is calculated using equation

$$
k_{j}= \begin{cases}1 & j=1 \\ s_{j}+1 & j>1\end{cases}
$$

Step 4: "Calculation of qj variable": The variable qj is calculated using equation 2.

$$
q_{j}= \begin{cases}1, & \mathrm{j}=1 \\ \frac{k_{j}-1}{k_{j}} & \mathrm{j}>1\end{cases}
$$

Step 5: "Determining Criteria Importance": The relative weights of the evaluation criteria are calculated using equation 3 . (wj), (j). indicates the relative weight of the criterion.

$$
w_{j}=\frac{q_{j}}{\sum q_{j}}
$$

\section{Multi Attribute Utility Theory (MAUT)}

The MAUT method aims to provide maximum utility to problems that are inconsistent with each other and have multiple criteria (Ömürbek, Delibaş and Altın, 2017). In the MAUT method, the steps can be listed as follows (Zietsman, Rilett and Kim, 2006):

Step 1: Creating the Decision Matrix: In the fifth stage of the first model of the MAUT method, an mxn dimensional decision matrix is created. The column elements of the decision matrix show the selection criteria, while the row elements indicate the decision points. Decision matrix $\mathrm{X}$ is shown in equation 4 . 


$$
X=\left[\begin{array}{cccc}
x_{11} & x_{12} & \ldots & x_{1 n} \\
x_{21} & x_{22} & \ldots & x_{2 n} \\
\cdot & & & \cdot \\
\cdot & & & \cdot \\
\cdot & & & \cdot \\
x_{m 1} & x_{m 2} & \ldots & x_{m n}
\end{array}\right]
$$

Step 2: Creating the Normalized Matrix: In the sixth step, the elements of the decision matrix are normalized by using equation 5 .

$$
u_{i}\left(x_{i}\right)=\frac{x_{i}-x^{-}}{x^{+}-x^{-}}
$$

After the operations, the normalized matrix $U$ shown in equation 6 is formed.

$$
U=\left[\begin{array}{cccc}
u_{11} & u_{12} & \ldots & u_{1 n} \\
u_{21} & u_{22} & \ldots & u_{2 n} \\
\cdot & & & \cdot \\
\cdot & & & \cdot \\
\cdot & & & \cdot \\
u_{m 1} & u_{m 2} & \ldots & u_{m n}
\end{array}\right]
$$

Step 3: Creating the Weighted Normalized Matrix: At this stage, the normalized matrix elements are multiplied by the weight values defined for their columns, and the weighted normalized matrix $\mathrm{U}^{*}$ is created as shown in equation 7.

$$
U^{*}=\left[\begin{array}{cccc}
w_{1} u_{11} & w_{2} u_{12} & \ldots & w_{n} u_{1 n} \\
w_{1} u_{21} & w_{2} u_{22} & \ldots & w_{n} u_{2 n} \\
\cdot & & & \cdot \\
\cdot & & & \cdot \\
\cdot & & & \cdot \\
w_{1} u_{m 1} & w_{2} u_{m 2} & \ldots & w_{n} u_{m n}
\end{array}\right]
$$

Step 4: Calculation of Result Distributions: In the last stage, the utility scores of decision alternatives are obtained by taking the sum of each row of the weighted normalized matrix $U$ and the decision alternatives are listed starting from the highest value. 


\section{ANALYSIS}

During the implementation process, first of all, decision-makers were asked about the race boats they used or were fully informed about, and they were also asked to list the selection criteria effective in the selection of these race boats. Subsequently, decision makers were asked to eliminate these alternatives and criteria. The final criteria and alternatives obtained were included in the evaluation process. Rowing clubs' managers and trainers have been determined as decision makers. These people are experts who have worked as athletes and trainers in rowing before and work in managerial positions.

Table 3. Factors affecting race boat selection and decision alternatives

\begin{tabular}{cccc}
\hline Code & Selection Criteria (Factor) & Code & Alternative \\
\hline C1 & Boat price & P1 & Brand-F \\
\hline C2 & Boat brand recognition & P2 & Brand-E \\
\hline C3 & Boat quality & P3 & Brand-H \\
\hline C4 & The purpose of use of the boat & P4 & Brand-W \\
\hline C5 & Characteristics of athletes & & \\
\hline C6 & Boat delivery time & \\
\hline C7 & Technical support & \\
\hline
\end{tabular}

Then, numerical values of selection criteria and decision alternatives were determined using the SAW method. Table 4 shows the mentioned weight values.

Table 4. Sorting criteria according to the SWARA method

\begin{tabular}{ccccccccc}
\hline Code & Criteria & $\begin{array}{c}\text { Rank of } \\
\text { Importance }\end{array}$ & $\begin{array}{c}\text { Ordered } \\
\text { Criteria }\end{array}$ & $(\mathbf{S j})$ & $(\mathbf{k j})$ & $(\mathbf{q j})$ & $(\mathbf{w j})$ \\
\hline $\mathbf{C}_{\mathbf{1}}$ & Boat price & 4 & $\mathrm{C}_{3}$ & 1 & & 1.000 & 1.000 & 0.193 \\
\hline $\mathbf{C}_{\mathbf{2}}$ & Boat brand recognition & 2 & $\mathrm{C}_{2}$ & 2 & 0.10 & 1.100 & 0.909 & 0.176 \\
\hline $\mathbf{C}_{\mathbf{3}}$ & Boat quality & 1 & $\mathrm{C}_{4}$ & 3 & 0.15 & 1.150 & 0.791 & 0.153 \\
\hline $\mathbf{C}_{\mathbf{4}}$ & The purpose of use of the boat & 3 & $\mathrm{C}_{1}$ & 4 & 0.08 & 1.080 & 0.732 & 0.141 \\
\hline $\mathbf{C}_{5}$ & Characteristics of athletes & 5 & $\mathrm{C}_{5}$ & 5 & 0.12 & 1.120 & 0.654 & 0.126 \\
\hline $\mathbf{C}_{\mathbf{6}}$ & Boat delivery time & 7 & $\mathrm{C}_{7}$ & 6 & 0.14 & 1.140 & 0.573 & 0.111 \\
\hline $\mathbf{C}_{7}$ & Technical support & 6 & $\mathrm{C}_{6}$ & 7 & 0.10 & 1.100 & 0.521 & 0.101 \\
\hline
\end{tabular}

After the weight values were calculated, MAUT method was used to rank the decision alternatives.

Table 5. Decision matrix $X$

\begin{tabular}{cccccccc}
\hline & $\mathbf{C}_{\mathbf{1}}$ & $\mathbf{C}_{\mathbf{2}}$ & $\mathbf{C}_{\mathbf{3}}$ & $\mathbf{C}_{\mathbf{4}}$ & $\mathbf{C}_{\mathbf{5}}$ & $\mathbf{C}_{\mathbf{6}}$ & $\mathbf{C}_{\mathbf{7}}$ \\
\hline $\mathbf{P}_{\mathbf{1}}$ & 9 & 9 & 8 & 9 & 9 & 9 & 9 \\
\hline $\mathbf{P}_{\mathbf{2}}$ & 8 & 9 & 9 & 9 & 8 & 7 & 9 \\
\hline $\mathbf{P}_{\mathbf{3}}$ & 8 & 7 & 6 & 7 & 7 & 5 & 6 \\
\hline $\mathbf{P}_{\mathbf{4}}$ & 9 & 5 & 4 & 5 & 5 & 3 & 4 \\
\hline $\mathbf{w}$ & 0.193 & 0.176 & 0.153 & 0.141 & 0.126 & 0.111 & 0.101 \\
\hline $\mathbf{u}+$ & 9 & 9 & 9 & 9 & 9 & 9 & 9 \\
\hline $\mathbf{u}-$ & 8 & 5 & 4 & 5 & 5 & 3 & 4 \\
\hline
\end{tabular}

As presented in Table 5, the smallest and largest values were determined for each selection criterion. Then, with the help of equation 5, the values of the decision matrix elements were normalized and a normalized matrix was formed (Table 6).

Table 6. Normalized matrix U 


\begin{tabular}{lccccccc}
\hline & $\mathbf{C}_{\mathbf{1}}$ & $\mathbf{C}_{\mathbf{2}}$ & $\mathbf{C}_{\mathbf{3}}$ & $\mathbf{C}_{\mathbf{4}}$ & $\mathbf{C}_{\mathbf{5}}$ & $\mathbf{C}_{\mathbf{6}}$ & $\mathbf{C}_{\mathbf{7}}$ \\
\hline $\mathbf{P}_{\mathbf{1}}$ & 1.000 & 1.000 & 0.800 & 1.000 & 1.000 & 1.000 & 1.000 \\
\hline $\mathbf{P}_{\mathbf{2}}$ & 0.000 & 1.000 & 1.000 & 1.000 & 0.750 & 0.667 & 1.000 \\
\hline $\mathbf{P}_{\mathbf{3}}$ & 0.000 & 0.500 & 0.400 & 0.500 & 0.500 & 0.333 & 0.400 \\
\hline $\mathbf{P}_{\mathbf{4}}$ & 1.000 & 0.000 & 0.000 & 0.000 & 0.000 & 0.000 & 0.000 \\
\hline
\end{tabular}

In the next step, the element values in each column of the normalized matrix are multiplied by the calculated weight value (wj) for its column, and the weighted normalized matrix is formed in Table 7.

Table 7. Weighted normalized matrix U

\begin{tabular}{lccccccc}
\hline & $\mathbf{C}_{\mathbf{1}}$ & $\mathbf{C}_{\mathbf{2}}$ & $\mathbf{C}_{\mathbf{3}}$ & $\mathbf{C}_{\mathbf{4}}$ & $\mathbf{C}_{\mathbf{5}}$ & $\mathbf{C}_{\mathbf{6}}$ & $\mathbf{C}_{\mathbf{7}}$ \\
\hline $\mathbf{P}_{\mathbf{1}}$ & 0.176 & 0.176 & 0.140 & 0.176 & 0.176 & 0.176 & 0.176 \\
\hline $\mathbf{P}_{\mathbf{2}}$ & 0.000 & 0.176 & 0.176 & 0.176 & 0.132 & 0.117 & 0.176 \\
\hline $\mathbf{P}_{\mathbf{3}}$ & 0.000 & 0.088 & 0.070 & 0.088 & 0.088 & 0.059 & 0.070 \\
\hline $\mathbf{P}_{4}$ & 0.176 & 0.000 & 0.000 & 0.000 & 0.000 & 0.000 & 0.000 \\
\hline
\end{tabular}

Finally, the relative importance values of decision alternatives are calculated by taking the mean value of each row of the weighted normalized matrix. Based on this value, decision alternatives for racing boats are listed in Table 8 .

Table 8. Performance scores and ranking of alternatives in race boat selection

\begin{tabular}{cccc}
\hline Code & Selection Criteria (Factor) & Score & Rank \\
\hline $\mathbf{P}_{1}$ & Brand-F & 1.194 & 1 \\
\hline $\mathbf{P}_{2}$ & Brand-E & 0.951 & 2 \\
\hline $\mathbf{P}_{3}$ & Brand-H & 0.462 & 3 \\
\hline $\mathbf{P}_{4}$ & Brand-W & 0.176 & 4 \\
\hline
\end{tabular}

\section{DISCUSSION}

The results obtained show that the proposed model is an effective approach that can be used as a methodological framework to solve decision making problems in rowing and other branches. In the criteria weighting process, in addition to the order that decision makers initially predicted, their estimates for decision alternatives were confirmed. On the other hand, the proposed model is a model that can be easily applied by decision makers and at the same time has extremely simple and understandable application steps. In this respect, it can greatly facilitate the work of decision makers in complex and time-consuming decision-making processes, and can be easily applied by almost every decision-maker as it does not require high-level programming or mathematical skills. In addition to this, the model can be further developed and expanded by adding different methods to the proposed model for the solution of decision-making problems arising in the field of sports in future studies. At the same time, the sequencing performance of objective and subjective methods can be compared in future conflicts.

\section{CONCLUSION}

In the final evaluation of the results obtained, it is seen that the selection criterion with the highest degree of importance is the "Boat Quality" criterion with a C3 coded value of $19.3 \%$. This is followed by the criterion "Boat brand recognition" C2 coded with $17.6 \%$ and "The purpose of use of the boat" C4 coded with $15.3 \%$. Therefore, economic factors are not as important as technical factors. As a result, decision makers give priority to technical criteria more than economic factors in boat selection. The most important factor for decision makers is 
winning races or performing high. It is highly possible that the factors that will ensure this are prioritized.

When the decision alternatives are examined, it is seen that the alternative with the highest relative importance value is Brand-F P1 coded, which ranks first with a performance score of 1.194, is followed by Brand-E with a score of 0.951. According to these results, the least preferred alternative brand with a performance score of 0.176 is the P4 coded Brand-W.

Rowing is a comprehensive sport practiced on multiple level of expertise. On one hand it's part of the Olympics, on the other hand universities and organizations organize races for their students and staff, also this sport is performed individually as a leisure activity. While performing rowing, it is important to use quality materials in order not to have an accident, considering that it is performed in various environmental conditions. The boat is the most valuable asset of the team, if the boat is not of good quality, the effort of the team for the race will not be sufficient. The Federation of Rowing Associations (FISA) sets certain standards for the boats to be used in races. At the same time, the federation has established a technical board to monitor and control the development of rowing equipment's. To ensure the safety of the athletes participating in the competitions, FISA pays attention to the quality of the equipment used in races, and reserves the right not to give the permission to the boats if the necessary conditions are not met. Which explains "boat quality" being the highest criteria in choosing equipments in our study.

A customer orders a boat for a specific purpose. The preferred hardness, weight and shape will vary according to the purpose of use. Since professional athletes need to have the highest quality equipment -unlike amateurs- boat quality and its purpose of use are closely related. It is logical that the customer who prioritizes quality, finds it important that the manufacturer brand is known. Well recognized brands are considered elite class boat manufacturers. They provide services as producing stylish and customized rowing boats which attract high-end customers. The durability of the product produced by the brand and the preservence of its value for many years is related to the reputation and recognition of the brand in that area. The fact that a brand is the manufacturer of rowing equipments used by the winning team in races may be a reason why this brand is preferred for other athletes. It is stated in some current sources that the boats produced by Filippi brand, which we determined to be the highest priority brand in our analysis results, are described as Ferrari among the other boats in this field. We think that the brand's emphasis on design has a great impact on this success. It is seen that the boats of the Filippi brand have won more than 400 medals in the Olympics in the past 20 years.

In first-class competitions, the characteristics that distinguish the winners from the losers are incomprehensible technical skills. Achieving this level of success and maintaining this level throughout the race makes rowing extremely attractive. In this study, the selection of equipment, which has a very important place in achieving success in rowing, has been discussed with a technique that has not been exemplified before in the literature.

As a result, the model used in this study has a form that can contribute to other studies. Therefore, it can be easily applied to decision-making problems encountered in the field of sports, especially rowing. In this respect, it has a quality level that can make important contributions to filling the gap in the literature related to similar sports fields. 


\section{REFERENCES}

Aytaç, K. Y., Yenel, İ. F. (2012). Taraftarların spor kulüplerindeki lisanslı ürün pazarlama faaliyetlerine ilişkin tutulan takım değişkenine göre satın alma tutumlarının incelenmesi. Adlyaman Üniversitesi Sosyal Bilimler Enstitüsü Dergisi, (9), 11-31.

Devecioğlu, S. (2005). Türkiye'de spor sektörü stratejilerinin geliştirilmesi. Verimlilik Dergisi, 2, 117-134.

Dorukkaya, Ş. (2000). Beden eğitimi ve spor istanbul olimpiyatları (Sekizinci beş yıllık kalkınma planı). Özel İhtisas Komisyon Raporu, D.P.T.Yayınları, Ankara.

Karaköprü, U. O., Kabadurmuş, Ö. (2019). Using multi-criteria decision-making methods to make logistics decisions in sports clubs. Alphanumeric Journal, 7(1), 129-142.

Keršuliene, V., Zavadskas, E. K., Turskis, Z. (2010). Selection of rational dispute resolution method by applying new step-wise weight assessment ratio analysis (SWARA). Journal of Business Economics and Management, 11(2), 243-258.

Lambert, D. M., Stock, J. R. (2001). Strategic Logistics Management. Singapore: McGraw Hill International Edition.

Ömürbek, N., Delibaş, D., Altın, F. G. (2017). ENTROPI temelli MAUT yöntemine göre devlet üniversiteleri kütüphanelerinin değerlendirilmesi. Selçuk Üniversitesi, Sosyal ve Teknik Araştırmalar Dergisi, (13), 72-89.

Özbek, A., Demirkol, İ. (2018). Lojistik sektöründe faaliyet gösteren işletmelerin SWARA ve GİA yöntemleri ile analizi. Kırıkkale Üniversitesi Sosyal Bilimler Dergisi, 8(1), 71-86.

Roscoe, S., Baker, P. (2014). Supply chain segmentation in the sporting goods industry. International Journal of Logistics Research and Applications, 17(2), 136-155.

Subaşı, M. (2019). Spor organizasyonlarındaki lojistik faaliyetlerin katılımcı memnuniyetine etkisi: Sapanca kürek parkuru, ulusal kürek yarışları. Master's thesis, İstanbul Gelişim Üniversitesi Sosyal Bilimler Enstitüsü.

Tanyaş, M. (2009). Lojistik Kavram ve Terimler Rehber Kitabı. Akademi Lojistik, Mersin Ticaret ve Sanayi Odası.

Tarakçı, İ. E., Baş, M. (2018). Bütünleşik pazarlama iletişiminde spor sponsorluğu ve tüketici satın alma davranışı üzerindeki etkisi. Third Sector Social Economic Review, 53(1), 291-326.

Türkiye Kürek Federasyonu. (2020). Federasyon tarihçesi. Access link: http://www.tkf.gov.tr/1/federasyontarihcesi-377.aspx. Access Date: 12.04.2020

Üçışık, H. F., Ekren, N. (2000). Spor sektörünün piyasa yapısı: teorik bir yaklaşım. Marmara Üniversitesi, III. Spor Bilimleri Kongresi, 11-13.

Zietsman, J., Rilett, L. R., Kim, S. J. (2006). Transportation corridor decision-making with multi-attribute utility theory. International Journal of Management and decision making, 7(2-3), 254-266. 